\title{
The effect of organic fertilizer and dolomite application toward cassava production in Lebak Regency-Banten
}

\author{
Viktor Siagian ", and Ismatul Hidayah \\ Assessment Institute for Agricultural Technology of Banten, Indonesia Ministry of \\ Agriculture, Ciptayasa Avenue-Serang-Banten Km 01 42182, Indonesia
}

\begin{abstract}
Cassava (Manihot esculenta C.) is the third-largest crop after rice, and corn in Banten Province. The objectives of this study are: 1) Determine the effect of organic fertilizer application and liming on cassava production in Lebak Regency, 2) Study the difference of cassava farming on the demonstration plot with the cassava farming of farmers. The research method uses a completely randomized experimental design (CRD) on a 0.5 ha demonstration plot with 3 treatment plots each with 3 replications. Also with the survey method interviewing 11 cassava farmers as respondents. The data analysis using qualitative and quantitative analysis. Quantitative analysis used the ANOVA (Analysis of Variance) test and the qualitative test used descriptive tabulations. The results of this study were 1) $\mathrm{F}_{\text {count }}=0.767<$ Ftable $=5,143$, the conclusion that $\mathrm{H}_{0}$ was received, means that all treatment did not significantly affect cassava productivity. 2) The average productivity of cassava on the demonstration plot was 42.13 tons of wet tubers/ha while at the farmer's level was 24.18 tons of wet tubers/ha with a $\mathrm{B} / \mathrm{C}$ ratiowas 4.0. The varieties plantedwere Manggu Local Superior Varieties both on the demonstration plot and farmers.
\end{abstract}

\section{Introduction}

Banten Province in 2017 produced 75,486 tons of cassava from a harvested area of 3,694 ha. Based on its administration, Lebak Regency has the largest production, which is 26,285 tons $(34.8 \%$ of total production) with a harvested area of 1,289 ha $(34.9 \%$ of the total harvested area) [1]. Based on CBS data (2017), the harvested area of cassava in Lebak Regency in 2016 was 1,246 ha with a production of 29,759 tons (productivity 23.88 tons $\mathrm{ha}^{-1}$ ) [2]. Sajira district is one of the centers of cassava production with a harvested area of 93 ha and a production of 2,712 tons or a productivity of 29.2 tons $\mathrm{ha}^{-1}$. Cassava is the third largest crop after rice and maize in Banten Province.

\footnotetext{
*Corresponding author: siagian.vicky@yahoo.com
} 
Cassava can be harvested from the age of 7-11 months or more. Cassava farming can be done in monoculture and intercropping because it is technically and financially profitable, even intercropping can reduce erosion by $20-40 \%$ [3].

One of the problems in the production of cassava is the level of productivity is still relatively low. Based on the study of [4], several superior varieties of cassava that have been released by the National Agricultural Research and Development Agency (AARD) are Adira-1 with a potential yield of 22.0 tons $\mathrm{ha}^{-1}$, Malang-1 (36.5 tons ha $\left.{ }^{-1}\right)$, Malang -2 (31.5 tons $\left.\mathrm{ha}^{-1}\right)$, Darul Hidayah $\left(102.1\right.$ tons $\left.\mathrm{ha}^{-1}\right)$. In monoculture cassava cultivation, fertilizer recommendations are in the form of Urea $200 \mathrm{~kg} \mathrm{ha}^{-1}, \mathrm{SP}-36100 \mathrm{~kg} \mathrm{ha}^{-1}$ and $\mathrm{KCl} 100 \mathrm{~kg}$ $\mathrm{ha}^{-1}[5]$.

[6] in their research in Lampung found that, various cassava varieties namely Adira-4, Rayong 60, Rayong 90, Kasetsart 50, and CMR30-56-1, when subjected to a long dry period during the growth cycle, both the fresh root yield and starch yield of all tested varieties decreased. [7] in their research in Lampung found that minimum tillage and herbicide increased cassava growth the most compared to perfect tillage + herbicide, minimum tillage and perfect tillage.

Sukarame Village, Sajira District, Lebak Regency is the location of the cassava-based bioindustry model activity with the integration of sheep in Banten Province which has been carried out since 2015. At the initial stage (in 2015) a 40 ha cassava cultivation technology pilot was carried out (assistance for 20 activities). ha and 20 ha for self-help farmers), while in 2016 it grew to 65 ha (15 ha for activities and 50 ha for non-governmental organizations). Furthermore, in 2017 , cassava planting only reached about 15 ha (5 ha for activities and 10 ha for self-help farmers) [8] [9].

The purpose of this study was to determine the effect of application of chemical fertilization, organic fertilization and liming on cassava productivity and compare its productivity with local farmers' yields.

\section{Methodology}

\subsection{Research method and data collection}

The location chosen for this research were Sukarame and Calungbungur Villages, Sajira District, Lebak Regency, which was chosen purposively. This is because in this district there has been a research activity "Development of a cassava-based bio-industrial area which has been going on since 2015 [8] [9]. The total of the respondent was taken for survey socio-economic of cassava farming are 11 respondents, the survey was conducted in October 2018.

The method used was a pilot method and survey method. Primary data collection at the farm level was done purposively because the number of farmers was limited, by conducting interviews using structured questionnaires. Secondary data collection and literature study were also conducted from internet browsing and related agencies such as the Banten Provincial Agriculture and Animal Husbandry Office, District Agriculture Services, and the Banten Provincial Central Statistics Agency,

The pilot method was carried out using the demonstration plot method on an area of 0.5 ha in the village of Calung Bungur, Sajira District in the Hade Hate farmer group land. The goal of the plot method was that farmers can increase their productivity through demonstration farming technology. The study period is for one year starting from January 2018 to December 2018.

This demonstration plotted (Demplot) consisted of three treatments and each of three replications with superior local varieties Manggu. The treatment made was a different type 
of fertilizer in each treatment and dolomite. The first treatment $\left(\mathrm{P}_{1} \mathrm{U}_{1}, \mathrm{P}_{1} \mathrm{U}_{2}, \mathrm{P}_{1} \mathrm{U}_{3}\right)$ was manure 4 ton $\mathrm{ha}^{-1}$, Urea fertilizer $200 \mathrm{~kg} \mathrm{ha}^{-1}$, NPK Ponska fertilizer $400 \mathrm{~kg} \mathrm{ha}^{-1}$, the second treatment $\left(\mathrm{P}_{2} \mathrm{U}_{1}, \mathrm{P}_{2} \mathrm{U}_{2}, \mathrm{P}_{3} \mathrm{U}_{3}\right)$ was manure, Urea and NPK Ponska equal to the first treatment plus Petrogenic $898.2 \mathrm{~kg} \mathrm{ha}^{-1}$, the third treatment $\left(\mathrm{P}_{3} \mathrm{U}_{1}, \mathrm{P}_{3}, \mathrm{U}_{2}, \mathrm{P}_{3} \mathrm{U}_{3}\right)$ is Manure, Urea, NPK and Petrogenic are the same as before added $898.2 \mathrm{kgs} \mathrm{ha}^{-1}$ dolomite. Also given a sketch of land layout for 3 treatments and 3 replications and $6 \mathrm{~kg}$ Furadan pesticides (for anti-termites on cassava cuttings). Wilson and Ovid in their research in Tobago and Trinidad (1994) [10] have proven that application doses of fertilizers influence the production of cassava. It was obtained using $400 \mathrm{~N}, 200 \mathrm{P}, 400 \mathrm{~kg} \mathrm{~K} / \mathrm{ha}$ fertilizer produced $63.1 \mathrm{t}$ fresh tubers/ha. However, this was similar to the yield obtained with a 400 $\mathrm{kgs} \mathrm{ha}^{-1} \mathrm{~N}$ and $\mathrm{K}$ fertilizer that produced 62.8 tons fresh tubers ha ${ }^{-1}$ ).

\subsection{Data Analysis}

Analysis of the data used consists of qualitative and quantitative analysis. Qualitative analysis using descriptive statistics and quantitative analysis using analysis of variance (ANOVA) to see treatments that affect the productivity of cassava on a 0.5 ha demonstration plot with a completely randomized design (CRD). If the ANOVA result

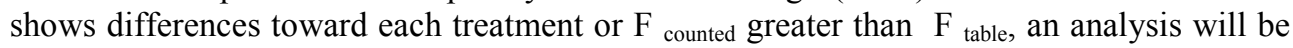
followed by posthoc test (Least Significant Difference or LSD, Honest Significant Difference or Tukey or HSD, and the Duncan test) (Mattjik and Sumertajaya 2013) [11]. Existing data is processed computerized, for tabulation analysis and $\mathrm{B} / \mathrm{C}$ ratio and ANOVA are processed with Macro function in Excel MS Office 2013 program.

In the analysis of cassava farming, to find out the benefits of each cost expensed, the Benefit-Cost $(\mathrm{B} / \mathrm{C})$ ratio analysis is used. The $\mathrm{B} / \mathrm{C}$ ratio value must be more than 1 so that cassava farming is profitable. While the Revenue Cost $(\mathrm{R} / \mathrm{C}$ ratio) analysis is used to find out how much the value of revenue received from each cost expensed. The $\mathrm{R} / \mathrm{C}$ ratio value must be greater than 2 for the farming to be profitable.

\section{Resulted and Discussion}

\subsection{Characteristics of Respondents}

Table 1. Characteristics of farmer respondents.

\begin{tabular}{|l|l|c|c|}
\hline No. & \multicolumn{1}{|c|}{ Items } & Mean & Range \\
\hline 1. & Age & 37.1 & $20-68$ years \\
\hline 2. & Length of education & 7.1 years & $0-12$ years \\
\hline 3. & $\begin{array}{l}\text { Total land area: } \\
\text { consist of: }\end{array}$ & 3.9 ha & $0-9.5$ ha \\
\hline & -Owned Land area & 2.4 ha & $0-5.5$ ha \\
\hline & -Not owned land area & 1.5 ha & $0-9.5$ ha \\
\hline 4. & Based on land tipology, total land area consist of: & & \\
\hline & - Rain-fed rice fields & 0.7 ha & $0-4.6$ ha \\
\hline & - Dry land & 0.3 ha & $0-2.5$ ha \\
\hline & - Garden land & 2.1 ha & $0-13.75$ ha \\
\hline & - Yard land & 0.3 ha & $0-2.51$ ha \\
\hline & - Other & 0.5 ha & $0-2.0$ ha \\
\hline
\end{tabular}

The characteristics of the respondents are presented in table 1. Based on the resulted of a survey of 11 respondents it is known that the average age of respondents is 37.1 years 
with a range of 20 - 68 years. The length of formal education is 7.1 years with a range of 0 12 years. It is equivalent to grade 1 junior high school.

Based on the table is known that the average age of respondents is 37.1 years with a range of $20-68$ years, length of education is 7.1 years

\subsection{Analysis of Cassava Farming}

Table 2. Analysis of cassava farming per hectare in Sukarame Village, Sajira subdistrict, Lebak Regency in 2018.

\begin{tabular}{|c|c|c|c|c|}
\hline No. & Type of Input/Output & Volume & Price/Unit (IDR) & Value (IDR) \\
\hline \multirow[t]{2}{*}{1} & Seed (tube) & & & \\
\hline & a. not label & 10,000 & 0 & 0 \\
\hline \multirow[t]{8}{*}{2} & Fertlizer (kg): & & & 0 \\
\hline & a. Urea & 1.2 & 3,231 & 3,877 \\
\hline & b. SP-36 & 15.8 & 2,546 & 40,227 \\
\hline & c. $\mathrm{KCl}$ & 0.2 & 2,600 & 520 \\
\hline & e. NPK Ponska & 115.5 & $2,252.8$ & 260,198 \\
\hline & f. Manure fertilizer & $2,972.7$ & 183.5 & 545,490 \\
\hline & g. Solid organic fertilizer $(\mathrm{kg})$ & 45.5 & 1,800 & 81,900 \\
\hline & g. Other fertilizer $(\mathrm{kg})$ & 9.1 & 0 & 0 \\
\hline \multirow[t]{3}{*}{4} & Pesticide: & & & \\
\hline & a. Solid (kg) & 6 & $18,333.3$ & 110,000 \\
\hline & b. Fluid (1) & 0.2 & 0 & 0 \\
\hline \multirow[t]{2}{*}{5} & Herbicide: & & & \\
\hline & a. Fluid (1) & 9.3 & $69,436.3$ & 645,758 \\
\hline \multirow[t]{3}{*}{7} & Other: & & & \\
\hline & a. Tax of Bulidin andLand & & & 2,273 \\
\hline & b. Village fee & & & 3,273 \\
\hline \multirow[t]{6}{*}{8} & Cost of hired labour: & & & \\
\hline & a. Hired Labour (WMD) & 40.8 & $47,817.4$ & $19,50,950$ \\
\hline & b.Family Labour (WMD) & 6.6 & $17,965.5$ & 118,572 \\
\hline & c. Wage of Tractor service & 0.2 & 360,000 & 72,000 \\
\hline & d. Cost of family tractor. & 0.6 & 291,667 & 175,000 \\
\hline & e. Cost of family animal & 0.4 & 0 & 0 \\
\hline 9 & Total Cost & & & $4,010,038$ \\
\hline 10 & Revenue & $24,181.8$ & 859.1 & $20,774,584$ \\
\hline 11 & Income & & & $16,764,546$ \\
\hline 12 & $\mathrm{~B} / \mathrm{C}$ & & & 4.0 \\
\hline
\end{tabular}

\section{Explanation $: \mathrm{n}=11$ respondents}

Based on the table 2 it is known that the revenue of cassava farming is IDR 20.8 million with a total cost of IDR 4.01 million so that an income of IDR 16.8 million $^{-1}$ is obtained. Thus the $\mathrm{B} / \mathrm{C}$ ratio value is 4.0 , which means that each expensed IDR 1 will get a benefit of IDR 4 or the farm is profitable financally. The average productivity is 24.182 kgs ha ${ }^{-1}$ with a selling price of IDR $859.1 \mathrm{~kg}^{-1}$. Atman (2010) [12] in his research in West Sumatra found that productivity of Darul Hidayah variety namely 60 tons ha $^{-1}$ with $\mathrm{B} / \mathrm{C}$ ratio value was 2.46. Also, [13] in Bali province found that productivity of Gajah variety was 31.59 tons $\mathrm{ha}^{-1}$ with $\mathrm{B} / \mathrm{C}$ ratio value was 2.0. The results of the [14] in Pati Regency, Central Java Province about the productivity of cassava varieties UJ-3 and UJ-5 with a 
spacing of $1 \times 1 \mathrm{~m}^{2}$ and a dose of NPK fertilizer 150-220 kgs ha ${ }^{-1}$ and ZA $150-250 \mathrm{kgs} \mathrm{ha}^{-1}$ and manure 5 ton $\mathrm{ha}^{-1}$ yield of 30 tons $\mathrm{ha}^{-1}$ with a $\mathrm{B} / \mathrm{C}$ ratio of 2.18 .

A variety of cassava after the program is Manggu (superior local types that have been certified), other local varieties are Butter and Bread. In addition to cultivating the type of cassava above also cultivates the type of toxic cassava that is the local variety: Fault and Uje for starch flour. The current price of cassava is IDR $500 \mathrm{~kg}^{-1}$ if harvested in the field, whereas if purchased at home it is IDR $800 \mathrm{~kg}^{-1}$. The cassava market is a chip factory in Cisoka District. Tangerang, which is $35-40 \mathrm{~km}$ away with a sales volume of 4 ton week ${ }^{-1}$. Prices at the factory \pm IDR $1,800-2,000 \mathrm{~kg}^{-1}$.

\subsection{Demonstration Plot of Cassava in Dry Land in Sajira district}

\subsubsection{Agronomic Development}

Development of cassava cultivation business is carried out in the village of Calung Bungur which is a neighboring village with Sukarame. The consideration was carried out outside the village because efforts to increase the productivity of cassava had been carried out in the village since 2015 and were relatively successful because of increased productivity.

Before planting, a soil fertility survey was carried out, taking several samples at the demonstration plot location. Soil test results through the Dry Soil Test Kit (DSTK), status C is low, the need for organic fertilizer is 2 tons $\mathrm{ha}^{-1}$. $\mathrm{P}$ nutrient status is low, $\mathrm{K}$ is high, $\mathrm{pH} 5$ 6 , dolomite is low. The details are listed in the following Table 3. Because DSTK test resulted were only available for rice, corn, and soybean, so recommendations were used for corn as a proxy for cassava. This development was carried out with a pilot method by making a 0.5 ha demonstration plot on a Hade Hate farmer group land. Plant perforation is carried out with the size or dimensions of $20 \times 20 \times 20 \mathrm{~cm}^{3}$, planting distance of $1 \times 1 \mathrm{~m}^{2}$, and land processing is done without tillage, by cleaning the land of shrubs with herbicides and small hoe.

Table 3. Results of soil fertility test in the demonstration plots of Calung Bungur Village, Sajira District, 2018.

\begin{tabular}{|l|l|c|c|}
\hline No. & \multicolumn{1}{|c|}{ Nutrient } & Status & Needed/ha for maize \\
\hline 1. & Phosphorus (P) & Low & $250 \mathrm{~kg}$ \\
\hline 2. & Potassium (K) & High & $50 \mathrm{~kg}$ \\
\hline 3. & PH & $5-6$ & $750 \mathrm{~kg}$ \\
\hline 4. & Dolimite & Low & $2.000 \mathrm{~kg}$ \\
\hline 5. & C (organic fertilizer need) & Low & $350 \mathrm{~kg} \mathrm{ha}^{-1}$ \\
\hline 6. & Urea & & \\
\hline
\end{tabular}

The first planting was dated March 30, 2018, and was completed on April 24, 2018. Measurement of height and number of leaves was first carried out on May 3, 2018, as well as measuring boundary benchmarks for 9 boxes consisting of 3 treatments and 3 replications. The results of measurements of height and number of leaves are the highest plants $46 \mathrm{~cm}$ and the number of leaves 10 pcs that are planted on March 30, 2018. The lowest plant height is $10 \mathrm{~cm}$ with several leaves 5 pcs that are planting on April 10, 2018. Overall plants grow $95 \%$ and weeding the new $50 \%$.

The second measurement is done at the age of the plant at this time 80-90 days after planted (DAP). The tallest plant is $218.9 \mathrm{~cm}$ with a total of 40 leaves in the first box, which is planted on March 30, 2018. While the lowest is $49.8 \mathrm{~cm}$ with several 17 leaves, at 9th box or $\mathrm{P}_{3} \mathrm{U}_{1}$ which was planted on 10 April 2018. Empirically there was no pest attack. Giving manure 20 sacks @ 40 kgs sack $^{-1}$ has been given half and half again this week. 
The third measurement was carried out on August 9, 2018. Plants grow well despite a long dry season. The highest plant height is $304 \mathrm{~cm}$ in the second box with 42 leaves and the lowest is $67 \mathrm{~cm}$ with 20 leaves in the third box.

The fourth measurement was carried out on October 4, 2018. The plants grew somewhat stunted and thin because of the long dry season and only one rain fell. The highest plant height is $348 \mathrm{~cm}$ in the 1st box with 69 leaves and the lowest is $99 \mathrm{~cm}$ with 31 leaves in the third box. Furthermore, fertilizer is given with 30 sacks of $50 \mathrm{~kg}$ manure, $100 \mathrm{~kg}$ Urea, and $100 \mathrm{~kg}$ SP-36.

The measurement of plant height and the number of cassava leaf plots was carried out on November 13, 2018. Plants began to grow normally and about $30 \%$ were still trunked thin due to the long dry season and the new rain fell 2-3 times. Then also because fertilization was carried out in early October and weeding in the first week of November. The highest plant height is $397 \mathrm{~cm}$ in the second box with 58 leaves and the lowest is 123 $\mathrm{cm}$ with the number 34 leaves in the third box. On the advice of farmers, the fertilizer cooperators were no longer carried out because they were waiting for harvest in midDecember. In summary, the agronomic development of Manggu Local Superior Variety (LSV) is presented in table 4 below.

Table 4. Agronomic development of manggu local superior varieties in various treatments in Calung Bungur Village, Sajira District, Lebak Regency in Banten.

\begin{tabular}{|l|l|r|r|}
\hline \multirow{2}{*}{ Treatment } & \multirow{2}{*}{ Repeat } & \multicolumn{2}{c|}{ Observation Variable (mean) } \\
\cline { 3 - 4 } & & Plant Height & Number of leaves \\
\hline I & Mean & 187.0 & 34.3 \\
\hline & SD & 23.3 & 5.9 \\
\hline II & Mean & 180.2 & 28.7 \\
\hline & SD & 31.0 & 2.9 \\
\hline II & Mean & 187.8 & 34.4 \\
\hline & SD & 63.6 & 5.8 \\
\hline Total & Mean & $\mathbf{1 8 5 . 0}$ & $\mathbf{3 2 . 5}$ \\
\hline
\end{tabular}

\subsubsection{Demplot Production Results}

Table 5. Productivity Results of Cassava Based on the treatment and replication of a 0.5 ha demonstration plot in Calung Bungur Village, Sajira District, Lebak Regency in 2018.

\begin{tabular}{|c|c|c|c|c|}
\hline \multirow{3}{*}{ Repeat } & \multicolumn{3}{|c|}{ Treatment } & \\
\hline & \multicolumn{3}{|c|}{ Productivity $\left(\right.$ Ton $\left.^{-1}{ }^{-1}\right)$} & \\
\hline & P1 & P2 & P3 & Total \\
\hline 1 & 22.84 & 12.35 & 45.06 & \\
\hline 2 & 56.79 & 50.74 & 72.22 & \\
\hline 3 & 66.30 & 25.31 & 27.53 & \\
\hline Sum & 145.93 & 88.4 & 144.81 & 379.14 \\
\hline Mean & 48.64 & 29.47 & 48.27 & 42.13 \\
\hline
\end{tabular}

Explanation: ; $\mathrm{P}_{1}=1$-treatment, $\mathrm{P}_{2}=2$-treatment, $\mathrm{P}_{3}=3$-treatment.

Cassava harvest is carried out on December 19, 2018, before the measurement of plants was taken. The highest demonstration plot results were $377 \mathrm{~cm}$ with the number of leaves of 64 strands in the first treatment namely the $1 \mathrm{st}$ box and the lowest was $130 \mathrm{~cm}$ with the number of leaves $27 \mathrm{~cm}$. The production results based on the treatment of 45 samples of cassava trees are presented in table 5 below. 
Based on table 5 above the average productivity is 42.13 ton $\mathrm{ha}^{-1}$ with the highest productivity in the first treatment $\left(\mathrm{P}_{1}\right)$ which is 48.64 ton ha ${ }^{-1}$ and the lowest in $\mathrm{P}_{2}$ is 29.47 ton $\mathrm{ha}^{-1}$. The reason for this low yield is that it is below the target of 45-60 ton $\mathrm{ha}^{-1}$ because of the long dry season, namely for more than 4 months starting in June - October, it only rained once. Based on the data in table 3 above, it can be arranged in the Anova table. The analysis of the Variance (ANOVA) of the above demonstration plot is presented in the following table:

Table 6. ANOVA Table model of the effect of organic fertilizers and Calcification on cassava productivity using excell program.

\begin{tabular}{|c|c|c|c|c|c|}
\hline \multirow{2}{*}{ Source of Diversity } & \multirow{2}{*}{ df } & \multirow{2}{*}{ Sum of Square } & \multirow{2}{*}{ Central Square } & F counted & F Table \\
\hline & & & & \multicolumn{2}{|c|}{$\mathrm{F}_{0.05}(2,6)$} \\
\hline Treatment & 2 & 721.45 & 360.725 & 0.7673 & 5.143 \\
\hline Error & 6 & $2,820.8$ & 470.13 & & \\
\hline Total & 8 & $3,542.25$ & 830.86 & & \\
\hline
\end{tabular}

Based on table 6 above, Fhit $<$ Ftable is obtained, namely $0.7673<5.143$ which means that none of the treatments has a significant effect on the productivity of cassava. Because accept $\mathrm{H}_{0}$, further tests (LSD, Tukey, and Duncan) do not need to be done. By using the Minitab software version 16, ANOVA test data analysis was also performed. The results are the same as shown in the following table.

Table 7. ANOVA Table model of the effect of organic fertilizers and calcification on cassava productivity using minitab program.

\begin{tabular}{|l|r|r|r|r|r|r|}
\hline Source of Diversity & df & Sum of Square & Mean Square & F counted & \multirow{2}{*}{$P$} & \multicolumn{1}{c|}{ F Table } \\
\hline Treatment & 2 & 721 & 361 & 0.77 & 0.505 & 5.143 \\
\hline Error & 6 & 2,821 & 470 & & & \\
\hline Total & 8 & 3,542 & & & & \\
\hline
\end{tabular}

Based on the table 7, it is shown that the value of Fcounted is $0.77<5.143$ of $\mathrm{F}$ table. Also shown by P-value namely $0.505>0.05$. So the hypothesis is accepted H0 which means that none of the treatments has a significant effect on the productivity of cassava.

Based on research by [15], [16] in the Democratic Republic of the Congo, it was known that the combination of chicken manure with NPK chemical fertilizer provides the highest agronomic efficiency. [17], in their research with five varieties (Adira 4, Malang 4, UK R\&D 2, Cecek Ijo, and UJ 5) in Blora Regency, East Java Province found that high input was $200 \mathrm{~kg}$ Urea $+200 \mathrm{kgSP} 36+125 \mathrm{~kg} \mathrm{KCl}+5000 \mathrm{~kg}$ of manure gives a yield of 25.81 tons per ha lower than the moderate input $125 \mathrm{~kg}$ Urea $+150 \mathrm{~kg} \mathrm{SP} 36+100 \mathrm{KCl}$ with a yield of 27.29 tons per ha. [18] in their research about cassava in Kenya and Uganda found that giving NPK fertilizer and mineral fertilizer increased yields significantly. Based on the research of [19] in Brazil, found that harvest time and Nitrogen dosage affect yield and quality, also based on the research results of [20] in Tanzania, Kenya, and Ghana, it was known that applying $\mathrm{N}$ fertilizer will increase yields of cassava. But based on the research results of Agbaje and [21] in Nigeria, found that fertilizer influence on tuber yield was not significantly affected in early-planted cassava (April), but in late-planted cassava, a significant reduction in yields was observed from the application of 400 and $800 \mathrm{~kg} \mathrm{ha}^{-1}$ of NPK fertilizer. [22] found that cassava production was statistically similar both under inorganic or organic fertilizer treatments. [23] in his research in Nigeria, found that giving 
dolomite at a dosage of 5 ton $\mathrm{ha}^{-1}$ and gypsum 2.5 ton $^{-1}$ gave the highest yield of 9.5 tons of wet tuber $\mathrm{ha}^{-1}$, compared with 2.5 ton $\mathrm{ha}^{-1}$ of gypsum alone which produces 7.2 ton of wet tuber ha- ${ }^{-1}$.

Based on the study of [24] by literature review found that cassava cultivated with simple agronomic practices or minimum input cause soil nutrient depletion. It was shown that cassava does extract large amounts of nutrients, especially potassium (K). Based on [25] research, it was found that compared to the other food crops (rice, maize, soybean, peanut), cassava relatively needs more of K. According to [26] about the study was to assess the agronomic performance of ten varieties of cassava in the Western Region of Ghana on root rot disease. It was found out that all varieties used were probably susceptible to the root rot disease except Tek Bankye, even though the infection levels varied. The infections were influenced by location. According to [27], the main pests that reduce cassava yields are red mites, caterpillars, flour bedbugs, shield lice, and whitefly, while the main diseases are viruses, bacteria, and fungi (leaf spots, root rot, wilt, leaf blight, and African Cassava Mosaic). Damage and weight reduction of cassava can be caused physiologically that occurs 24-28 hours after harvesting, microbiological damage occurs 5-7 days after harvesting [28]. [29] in their research in Sao Paulo, Brazil, found that cassava's yield showed no response to limestone application, but responded to manure (organic fertilizer), producing $43 \mathrm{t} \mathrm{ha}^{-1}$ of roots at the rate of $8 \mathrm{t}$ ha-1 of manure. The treatments also did not influence soil density and total porosity. In addition, the addition of manure increased the concentrations of $\mathrm{P}$ and $\mathrm{K}$, while the addition of limestone increased $\mathrm{Ca}$ and $\mathrm{Mg}$ in the soil. The $\mathrm{pH}$ was affected only by limestone.

\section{Conclusions}

The average productivity of cassava on the demonstration plot is 42.13 tons of wet tubers $\mathrm{ha}^{-1}$ while at the farmer level is 24.18 tons of wet tubers $\mathrm{ha}^{-1}$ with a $\mathrm{B} / \mathrm{C}$ ratio value is 4.0 , which means that cassava farming is financially profitable. The varieties planted are Local Manggu Superior Variety both at demonstration plots and farmers.

$\mathrm{F}$ counted $<\mathrm{F}$ table, all treatments have no significant effect on cassava productivity. The highest productivity was in the first treatment which was 48.64 tons ha $^{-1}$ and the lowest in the second treatment which was 29.47 tons $\mathrm{ha}^{-1}$. The highest plant height and number of leaves were found in the third treatment namely $187.8 \mathrm{~cm}$ and 34.4 strands, and the lowest in the second treatment were $180.2 \mathrm{~cm}$ and 28.7 strands.

Thank you to AIAT Banten for funding this research and Mrs. Resmayeti Purba who also gave her advice and guidance on writing this paper.

\section{References}

1. CBS, Banten in Figure 2018 (Serang: Central Bureau of Statistics,2018)

2. CBS, Lebak in Figure 2017 (Rangkasbitung: Central Bureau of Statistics,2017)

3. Wargiono, J.A. Hasanuddin dan Suyamto Cassava Production Technology Supports the Bioethanol Industry.Center for Food Crops Research and Development. Bogor.p.41 (2006)

4. Sundari T. 2010. Introduction of Superior Varieties and Cassava Cultivation Techniques. The German Federal Ministry of Environment, Nature Conservation and Nuclear Safety and the Ministry of Forestry of Republic of Indonesia. Jakarta (2010) 
5. Mussadad A. Production Technology of Soybeans, Peanuts, Mung Beans, Cassava, and Sweet Potato. Center for research and development of food crops. Agency for Agricultural Research and Developmen, Bogor. (2008)

6. Fauzan, and Puspitorini Proceed of the sixth Regional workshop (2001)

7. Delyana, Lumbanraja J, Sunyoto, and Utomo M. J. Agrotek Tropika, 4 233-239 (2016)

8. Siagian V, Kardiyanto E, Lestari S, Amanda U, Rukmana T, Raswita T and Suhartin Bio Industrial Zone Development Cassava Based in Lebak Regency Banten Province (Serang: Assessment Institute for Agricultural Technology of Banten, 2018

9. Siagian V, Muharfiza, Fauzan A, Amanda U, Winanti N and Hendriansya J Bio Industrial Zone Development Cassava Based in Lebak Regency Banten Province (Serang: Assessment Institute for Agricultural Technology of Banten, 2019)

10. Wilson H and Ovid A. J. of Plant Nutr, 7 1127-1135 (1994)

11. Mattjik AA and Sumertajaya IM. Experiment Design: with SAS and Minitab Application (Bogor: IPB Press, 2013)

12. Atman. J. Penelit. Pertan. Terap, 11 56-68 (2010)

13. Mardika IN, Rantau IK and Wijayanti PU. E-J Agribisnis dan Agrowisata, 6.231239 (2017)

14. Nugraha HD, Suryanto and Nugroho A. J. Prod. Tan, 3 673-682 (2015)

15. Biratu GK, Elias E, Ntawuruhunga P and Sileshi GW. Heliyon J, 42 - 23 (2018)

16. Munyahali W, Pypers P, Swennen R, Walngululu J, Vanlauwe B, and Merkxc R. Field Crop.Res, 214194 - 201 (2107)

17. Wahyuningsih S and Sutrisno. Bul. Palawija, 17. 40-45 (2019)

18. Fermont AM, Tittonell PA, Baguma Y, Ntawuruhunga P and Giller KE. Nutr Cycl Agroecosyst, 86 133-151 (2010)

19. De Oliviera NT, Uchôa SCP and Alves JMA. Revista Bras Cienc Solo, 411 - 12 (2017)

20. Senkoro CJ, Tetteh FM, Kibunja CN, Keziah W and Magiroi N. J. of Soil Fertility and Crop Nutr, 1101600 - 1606 (2018)

21. Agbaje GO and Akinlosotu TA. African J. of Biotech, 3 547-551 (2004)

22. Ayoola OT and Makinde EA. Res. J. of Agric. and Biol. Sci, 3 13-20 (2007)

23. Anikwe MAN, Eze JC, and Ibudialo AN. J. Soil and Tillage Res, 158 32-38 (2016)

24. Howeler RH. Field Crops Res, 26 1-18 (1991)

25. Subandi. Bul. Palawija, 22 86-95 (2011)

26. Gyan J, Owusu J, Awasina RA. J. of Bio. Agric. and Healthcare, 8 34-41 (2018)

27. Saleh N, Inidanti SW and Rahayu M. Main Pest and Disease Control: Cassava Technology Innovation and Development Policy.(Bogor: Center for Research and Development of Food Crops,2009) pp 168-189

28. Erliana G. Post Harvest Handling of Cassava, Technology Innovation and Development Policy (Bogor: Center for Research and Development of Food Crops, 2009) pp 205-228

29. Ros AB,Narita N, Hirata ACS, Creste JE. J. Rev. Ceres, Viçosa, 67 23-29 (2020) 